\title{
DOES THE RISK MATTER? \\ THE STUDY OF THE EFFECT OF EARNINGS RISK ON EMPLOYEE MOBILITY IN THE LABOUR MARKET
}

This paper attempts to evaluate some implications of the risk of investment in human capital on employee mobility in the United Kingdom. Previous empirical studies showed that the earnings risk affects individual educational and occupational choices. However, the focus was not on the risk associated with investment in job-related training. Given the fact that training benefits for the employee (return on investment) can hardly be predicted accurately, it was hypothesized that financial (earnings) risk has a significant impact on employee labour market mobility. Using the rich panel data from the eighteen waves of the British Household Panel Survey, the study investigated the effect of the risk on employees' voluntary job changes. The results indicate that the higher risk of investment in job-related training leads to a higher probability of promotion or finding a new job.

Keywords: human capital, investment in training, earnings risk, labour market mobility

JEL Classification: J24, J21

DOI: 10.15611/aoe.2021.2.11

\section{INTRODUCTION}

The central focus of most European countries' education policy is on lifelong learning by promoting individual educational activity and encouraging employers to invest in employees' skills development. This seems to be quite reasonable in the light of the recent OECD survey results, which indicate that there is a high incidence of skill mismatch (measured at three levels: field of study, level of qualification, literacy rate) in the member countries (OECD, 2014) The European Commission supports this alarming information highlighting that "70 million Europeans lack adequate reading and writing skills, and even more have poor numeracy and digital skills, putting them at risk of unemployment, poverty and social exclusion" (A New Skills Agenda for Europe, 2016). At the same time, the problem of overeducation and overskilling has also attracted considerable attention in the literature [see, for

\footnotetext{
* Department of Education and Personnel Development, Poznan University of Economics and Business, Poland.
} 
example, Flisi, Goglio, Meroni, Rodrigues and Vera-Toscano, 2017; Mavromaras, McGuinness, Richardson, Sloane and Wei, 2011; Meliciani and Radicchia, 2016].

For underskilled workers, job-related training ${ }^{1}$ serves as an important complement to qualifications obtained within formal education, while for overskilled workers engaging in training might help to keep their skills up-todate (Ferreira, Künn-Nelen and De Grip, 2017). or make them more adaptable to the constantly changing environment. However, it should be noted that at no time in the last few decades has the speed of technological change been so fast. Not only does this lead to the emergence of new occupations and types of jobs, but skills that were sought by employers several years ago are no longer required. Staff are therefore expected to constantly update their skills and learn new occupational and job skills in order to meet labour market needs, regardless of their career stage. However, the future training relevance for the current and/or potential employer can hardly be known at the decision-making moment due to the fact that an employee might leave or move to a new position within the firm: an individual does not know to what extent the current or future job will enable them to apply newly acquired skills and knowledge. There are also numerous factors - both related to individual characteristics and external conditions - that are uncertain at the moment of making an investment decision. Therefore, the investor's abilities to accurately predict training outcomes and the level of return on investment are rather limited. As a consequence, not only employers but also primarily employees face the substantial risk associated with investment in work-related training.

Over the last few decades there has been growing interest in exploring the risk of investment in human capital. Several studies have focused on analysing how educational and occupational choices are affected by financial (earnings) risk, including those by Kodde (1986), Raita [2005], Bonin, Dohmen, Falk, Huffman and Sunde (2007), Bonin (2007), Cheng (2007), Diaz Serrano and Hartog (2007), and Hartog, Ding and Liao (2011).

A number of authors examined the relation between the risk of investment in human capital and labour market mobility. For example, McGoldrick and Robst [1996] empirically showed that higher risk is associated with the higher probability of labour market mobility. They also found that the effect is stronger for women. In a recent study the author focused on employees' expectations about future external and internal labour market mobility under different levels of earnings risk; no relation was found between the analysed variables (Shelest, 2015).

\footnotetext{
${ }^{1}$ In this article the terms "work-related training" and "job-related training" are used interchangeably.
} 
Several empirical studies suggest that there is a relation between attitude to the risk of investment in human capital and occupational choice (Bonin et al., 2007; Hartog and Diaz-Serrano, 2004; King, 1974). Argaw, Maier and Skriabikova (2013) found that individuals who show higher risk aversion are less inclined to change their jobs at an early stage of their professional career. Since labour market mobility can be perceived by individuals as a risky decision [Argaw et al., 2013], it can be expected that employees who face higher earnings risk associated with investment in human capital will be more mobile in the labour market.

While there is a substantial body of literature that investigates the risk of investment in human capital and labour market mobility as separate issues, the question of whether this risk has an impact on voluntary job changes has not been researched so far. The main objective of this paper was to examine the effect of the risk of investment in job-related training on labour market mobility. The empirical part of the research aimed to test the following hypothesis:

\subsection{Risk of investment in job-related training induces labour market mobility}

This paper contributes to two strands of the literature: one that studies the risk of investment in human capital and its impact on employees' educational and career choices, and another that focuses on the determinants of labour market mobility. This study used an estimation procedure that allowed to identify the risk associated with one particular type of investment in human capital, namely job-related training. The advantage of the proposed approach is in estimating the earnings risk separately for trained and non-trained individuals, based on the assumption that individuals who decide not to engage in work-related training also accept the risk. Additionally, in comparison to several previous studies, the author divided the research sample into two-digit occupation groups instead of using one-digit categories. The analysis was based on panel data from the first eighteen waves of The British Household Panel Survey.

The rest of the paper is structured as follows. The second section describes the data and the research sample. The third section presents the estimation methods and explains the research procedures. The fourth section reports and discusses the main findings. The fifth section presents the conclusions. 


\section{THE DATA AND RESEARCH SAMPLE SELECTION}

Data from the British Household Panel Survey (BHPS) ${ }^{2}$ were used to examine the impact of the risk of investment in training on voluntary job changes. The BHPS, which began in 1991, covers a nationally representative sample of British households. The survey provides extensive information on employees' working conditions, their educational background and employment history. Due to the fact that in 2010, BHPS became part of the Understanding Society survey, the data from the first 18 waves covering the period from 1991 to 2009 were analysed in the paper.

The focus of empirical research was on employed individuals aged 16-60. Information on each respondent's employment status was obtained from

\section{Table 1}

Number of respondents in the research sample

(according to the BHPS wave)

\begin{tabular}{l|c}
\hline \multicolumn{1}{c|}{ BHPS wave } & $\begin{array}{c}\text { Number of respondents included } \\
\text { in the research sample }\end{array}$ \\
\hline 1 & 2,523 \\
\hline 2 & 774 \\
\hline 3 & 2,198 \\
\hline 5 & 2,344 \\
\hline 6 & 2,305 \\
\hline 7 & 2,447 \\
\hline 9 & 2,586 \\
\hline 10 & 2,596 \\
\hline 11 & 2,523 \\
\hline 12 & 2,528 \\
\hline 13 & 2,463 \\
\hline 14 & 2,316 \\
\hline 15 & 2,175 \\
\hline 16 & 2,049 \\
\hline 18 & 2,064 \\
\hline
\end{tabular}

Source: own computations based on BHPS data.

\footnotetext{
2 The institution responsible for collecting the data is the ESRC Research Centre on Microsocial Change at the University of Essex. Access to the data was possible through the ESRC data archive (https://www.ukdataservice.ac.uk).
} 
a self-declaration of their current economic activity. Respondents who reported themselves as retired, full-time student, on maternity or sick leave, taking care of a family member or participating in government training programs were omitted from the sample. The study did not cover those who were selfemployed. In addition, the research sample included only persons employed full-time in the private sector. Table 1 presents the number of respondents from each BHPS wave that were included in the research sample.

With regard to employees who reported labour market mobility, only voluntary job changes were considered. This means that the analysis did not cover respondents who indicated one of the following reasons for leaving a previous job: made redundant; dismissed or sacked; temporary job ended; took retirement; stopped doing the job for health reasons, children/home care, care of other person; left to have a baby; other reasons. As a result, the final research sample covered respondents who found a better job and started working for a new employer or left their previous job because of promotion.

\section{METHODOLOGY}

\subsection{Measuring the risk of investment in training}

In the first stage of the empirical research, the risk of investment in jobrelated training was estimated. Although several methods can be used to estimate the risk of investment in human capital ${ }^{3}$, the most commonly used approach is based on employees' actual earnings (see, for example: McGoldrick and Robst (1996), McGoldrick (1995), Diaz-Serrano, Hartog and Skyt Nielsen (2008), Hartog (2002)). The advantage of such an approach lies in the fact that earnings can be easily observed by the researcher, whereas other possible outcomes of investment are either subjective in nature (level of motivation, job satisfaction, career satisfaction, etc.) or can hardly be measured accurately (changes in employees' productivity). Taking this into account, the author used information on respondents' hourly earnings and their participation in job-related training in order to estimate the earnings risk.

\footnotetext{
3 The most frequently used approaches to estimating the risk of investment in human capital are based on one of the following types of information: individual earnings level, residuals of individual earnings and the rate of return on investment in human capital. The most common statistical measures used to estimate the level of risk of investment in human capital include variance, standard deviation and quartiles. A common feature of the mentioned approaches is that they will only allow for estimating a financial risk rather than any other type of investor's risk (upcoming article).
} 
In order to calculate the risk, the Mincer-type earnings regression was estimated separately for each year. The equation, in which the dependent variable is the logarithm of the net hourly wage, is as follows:

$$
\ln W_{i}=\alpha_{0}+\beta \mathbf{x}_{i}+\varepsilon_{i},
$$

where $\alpha_{0}$ and $\beta$ are parameters of the model; $W_{i}$ denotes net hourly wage earned by an individual $i ; \mathbf{x}_{\mathrm{i}}$ covers level of education, age (as a proxy variable for work experience), age squared. There are also several control variables included in $\mathbf{x}_{\mathrm{i}}$, and $\varepsilon_{i}$ is an error term which reflects unobserved individuals' characteristics. A complete list and description of the independent variables included in $\mathbf{x}_{\mathrm{i}}$ can be found in Table 2 .

In previous studies on the risk of investment in human capital focused mainly on formal education, the set of independent variables was limited to typical human capital variables (educational level, age and age squared), basic demographic characteristics, and dummies for occupational/educational groups (see, for example, Diaz-Serrano et al., 2008; Hartog and Vijverberg, 2002). This approach, which is widely applied in the literature, was first used byMcGoldrick [1995], who assumed that a decision-maker has limited knowledge about the facts and conditions that will impact on future investment outcomes. Therefore, only variables that are known at a time of decisionmaking should be included in the regression. However, it should be remembered that the choice to engage in job-related training is usually made after entering the labour market. After starting a professional career, an individual acquires some additional information on working conditions, the internal labour market functioning and career prospects. This may strengthen her/his predictive abilities related to investment decisions. For that reason, it was necessary to incorporate in the earnings regression (1) additional independent variables that describe job attributes and an employer's characteristics. These included the type of contract (permanent/temporary), the type of position (managerial/ non-managerial), length of tenure, company size, and industry.

Additionally, in order to capture the essence of the financial risk associated with work-related training, a dummy variable that describes whether a respondent had participated in training or not was incorporated into the regression (1). This variable was derived from the respondents' answers about participating in training during the 12 months preceding the survey. It was also possible to distinguish between training courses that were related to the individuals' employment and other types of training courses. Obviously, the empirical analysis does not cover employees who reported participation in training courses that did not focus on job-related skills development. 
Table 2

Operationalizing definitions of the research variables used in the earnings regression

\begin{tabular}{|c|c|c|}
\hline Variables & Definition & Type of variable/scale \\
\hline 1 & 2 & 3 \\
\hline $\begin{array}{l}\text { LNWAGE } \\
\text { (outcome } \\
\text { variable) }\end{array}$ & $\begin{array}{l}\text { Logarithm of net hourly wage. Derived } \\
\text { from the variables PAYGU, JBHRS, } \\
\text { JBOTPD. }\end{array}$ & Numerical \\
\hline $\begin{array}{l}\text { EDUC1 - } \\
\text { EDUC12 }\end{array}$ & $\begin{array}{l}\text { The highest educational qualification. } \\
\text { Derived from the variable QFEDHI. }\end{array}$ & $\begin{array}{l}\text { Category: } \\
\text { 1) higher degree } \\
\text { 2) first degree } \\
\text { 3) teaching qualification } \\
\text { 4) other higher qualification } \\
\text { 5) nursing qualification } \\
\text { 6) GCEA levels } \\
\text { 7) GCE O levels or equivalent } \\
\text { 8) commercial qualification, no O levels } \\
\text { 9) CSE grade 2-5, Scottish grade 4-5 } \\
\text { 10) apprenticeship } \\
\text { 11) other qualification } \\
\text { 12) no qualification }\end{array}$ \\
\hline AGE & Respondent's age & Numerical \\
\hline $\mathrm{AGE}^{*} \mathrm{AGE}$ & Age squared. & Numerical \\
\hline JBTRAIN & $\begin{array}{l}\text { Participation in job-related training. } \\
\text { Derived from the variables JBED, } \\
\text { EDNEW (waves from } 1 \text { to } 7 \text { ), TRAIN } \\
\text { (waves from } 8 \text { to 18). Takes value } 1 \\
\text { if the respondent participated in job- } \\
\text { related training during the last } 12 \\
\text { months preceding the survey. }\end{array}$ & Dichotomous \\
\hline SEX & $\begin{array}{l}\text { Gender. Takes value } 1 \text { if the respondent } \\
\text { is a female. }\end{array}$ & Dichotomous \\
\hline MLSTAT & $\begin{array}{l}\text { Marital status. Takes value } 1 \text { if the } \\
\text { respondent is married. }\end{array}$ & Dichotomous \\
\hline $\begin{array}{l}\text { REGIO1 - } \\
\text { REGIO18 }\end{array}$ & $\begin{array}{l}\text { Region. Derived from the variable } \\
\text { REGION. }\end{array}$ & $\begin{array}{l}\text { Category: } \\
\text { 1) Inner London } \\
\text { 2) Outer London } \\
\text { 3) Remainder of South East } \\
\text { 4) South West } \\
\text { 5) East Anglia } \\
\text { 6) East Midlands } \\
\text { 7) West Midlands Conurbation } \\
\text { 8) Remainder of West Midlands } \\
\text { 9) Greater Manchester } \\
\text { 10) Merseyside } \\
\text { 11) Remainder of North West } \\
\text { 12) South Yorkshire } \\
\text { 13) West Yorkshire } \\
\text { 14) Humber } \\
\text { 15) Wear } \\
\text { 16) Remainder of North } \\
\text { 17) Wales } \\
\text { 18) Scotland }\end{array}$ \\
\hline
\end{tabular}


Table 2, cont.

\begin{tabular}{|c|c|c|}
\hline 1 & 2 & 3 \\
\hline JBTERM & $\begin{array}{l}\text { Type of employment. Takes value } 1 \text { if } \\
\text { the respondent has temporary contract. }\end{array}$ & Dichotomous \\
\hline JBMNGR & $\begin{array}{l}\text { Type of position occupied. Takes value } \\
1 \text { if the respondent has managerial } \\
\text { position. }\end{array}$ & Dichotomous \\
\hline JBTENURE & $\begin{array}{l}\text { Job tenure. Derived from the variables: } \\
\text { DOIY4, JBBGY4, DOIM, JBBGM. }\end{array}$ & Numerical \\
\hline $\begin{array}{l}\text { FSIZE1 - } \\
\text { FSIZE9 }\end{array}$ & $\begin{array}{l}\text { Size of the firm. The number of } \\
\text { employees was used as a proxy. } \\
\text { Derived from the variable JBSIZE. }\end{array}$ & $\begin{array}{l}\text { Category: } \\
\text { - } 1-2 \text { employees } \\
\text { - 3-9 employees } \\
\text { - 10-24 employees } \\
\text { - 25-49 employees } \\
\text { - 50-99 employees } \\
\text { - 100-199 employees } \\
\text { - 200-499 employees } \\
\text { - 500-999 employees } \\
\text { - }>1000 \text { employees }\end{array}$ \\
\hline $\begin{array}{l}\text { INDUSTRY1 - } \\
\text { INDUSTRY17 }\end{array}$ & $\begin{array}{l}\text { Industry (according to the UK } \\
\text { Standard Industrial Classification of } \\
\text { Economic Activities). Derived from } \\
\text { the variables: JBSIC (waves from } 1 \\
\text { to 11) and JBSIC92 (waves from } 12 \\
\text { to 18).* }\end{array}$ & $\begin{array}{l}\text { Category: } \\
\text { 1) Agriculture, Hunting and Forestry } \\
\text { 2) Fishing } \\
\text { 3) Mining and Quarrying } \\
\text { 4) Manufacturing } \\
\text { 5) Electricity, Gas and Water Supply } \\
\text { 6) Construction } \\
\text { 7) Wholesale and Retail Trade: Repair of } \\
\text { Motor Vehicles, Motorcycles and Personal } \\
\text { Household Goods } \\
\text { 8) Hotels and Restaurants } \\
\text { 9) Transport, Storage and Communication } \\
\text { 10) Financial Intermediation } \\
\text { 11) Real Estate, Renting and Business Activities } \\
\text { 12) Public Administration and Defence: } \\
\text { Compulsory Social Security } \\
\text { 13) Education } \\
\text { 14) Health and Social Work } \\
\text { 15) Other Community, Social and Personal } \\
\text { Service Activities } \\
\text { 16) Private Households with Employed Persons } \\
\text { 17) Extra-Territorial Organisations and Bodies }\end{array}$ \\
\hline XRWGHT & Weighting variable & Numerical \\
\hline
\end{tabular}

* In the BHPS survey, the information about industry is contained in two variables: jbsic, which uses the UK SIC 1980 classification and is available until 2001, and jbsic92, which uses the UK SIC 1992 classification and is available from 2001 onwards. In order to recode the variable jbsic the author used the algorithm proposed by Smith, which is available on http:// www2.warwick.ac.uk/fac/soc/economics/staff/jcsmith/sicmapping/resources/direct/ (accessed: 17.11.2018).

Source: own elaborations based on BHPS data. 
To compute the net hourly wage, the study used an approach similar to those applied by Booth, Francesconi and Zoega (2003). Table 2 presents the operationalization of the research variables used in the earnings regression.

Based on the result of the regression estimation, in the second stage of the empirical research the author computed earnings residuals as the difference between predicted values and observed values. The research sample was then divided into several occupation groups using the two-digit codes of the International Standard Classification of Occupations. Using more disaggregated information enabled to obtain different risk levels that reflect the occupation groups' specificity in terms of the job attributes and skills required.

In the study, work-related training is assumed to be occupation-specific rather than education specific. Next, each occupational group was divided into two subgroups: the first consisted of workers who had participated in jobrelated training in the last 12 months; the second group was made up of staff who had not attended any job-related training courses in the last 12 months. The occupation-specific earnings risk was computed separately for trained and for non-trained employees using the following formula:

$$
R_{j}=\frac{1}{N_{j}} \sum_{j}\left(e_{i j}-\bar{e}_{j}\right)^{2},
$$

where $R_{j}$ refers to the earnings risk; $e_{i j}$ is the exponential transformation on the earnings residuals; $N_{j}$ is the occupational group size measured as a number of individuals in group $j$. Residual variance $R_{j}$ serves as a measure for individual earnings risk for all workers who belong to occupational group $j$. Higher values of earnings residuals variability within the occupational group indicate the higher level of occupation-specific financial (earnings) risk.

\subsection{Econometric model of the effect of the earnings risk on employee' mobility}

To examine the impact of the risks of investment in job-related training on employees' voluntary mobility, the study specified a simple model with a binary dependent variable. In such a model, the binary variable represents a continuous variable which cannot be observed by the researcher (the socalled latent variable). In the case of labour mobility, the latent variable may refer to either the individual tendency to move to another job or the net benefit of changing job. Both variables can hardly be measured by the researcher. Instead of some latent variable $Y^{*}$, one can observe variable $Y$ which takes a value of 1 when $Y^{*}>0$, and 0 otherwise. 
Let $M_{i j}^{*}$ be a latent variable whose values cannot be observed, even though actual job changes are observable. Then $M_{i j}^{*}$ is reflected by variable $M_{i j}$, which equals 1 when $M_{i j}^{*}>0$, and 0 otherwise. The model which describes the impact on labour market mobility of the risk of investment in work-related training can be written as:

$$
M_{i j}^{*}=\alpha_{0}+\alpha_{1} R_{i t}+\sum_{j=2}^{k} \alpha_{j} \mathbf{x}_{i t}+\varepsilon_{i t},
$$

where $M_{i j}^{*}$ is a latent outcome variable; $R_{i t}$ is a variable which denotes the earnings risk of investment in job-related training; $\mathbf{x}_{\mathrm{it}}$ represents a vector of control variables; $\varepsilon_{i t}$ is an error term; $\alpha_{j}$ are the parameters of the model to be estimated; $\mathrm{t}$ is year of observation. The values of $R_{i t}$ were computed based on equation (2) that was presented in sub-section 3.1.

In order to estimate the effect of the earnings risk on employees' mobility, the study used a fixed effects estimator. In the case of panel data, this approach allows for a correction of respondents' unobservable characteristics which do not change over time [Morgan, 2013], but which correlate with other explanatory variables in the model [Andreß, Golsch and Schmidt, 2013] . Equation (3) can be rewritten as follows:

$$
M_{i j}^{*}=\alpha_{0}+\alpha_{1} R_{i t}+\sum_{j=2}^{k} \alpha_{j} \mathbf{x}_{i t}+u_{i}+\varepsilon_{i t},
$$

where $u_{i}$ includes unobservable individual characteristics and does not change over time.

Under the assumption that the error term $\varepsilon_{i t}$ has a logistic distribution, it is possible to estimate the probability of labour market mobility using a logit model. In accordance with the standard approach, the probability of the two possible outcomes (voluntary job change and lack of mobility) can be written as follows:

$$
\begin{aligned}
& \operatorname{Prob}\left(M_{i t}=0\right)=\frac{1}{1+e^{z}}, \\
& \operatorname{Prob}\left(M_{i t}=1\right)=\frac{e^{z}}{1+e^{z}},
\end{aligned}
$$

where $z_{i t}=\alpha_{0}+\alpha_{1} R_{i t}+\sum_{j=2}^{k} \alpha_{j} \mathbf{x}_{i t}+u_{i}$.

\footnotetext{
${ }^{4}$ For fixed effects model assumptions see, for example, [Andreß et al., 2013, p. 135].
} 
The final probability model to be estimated is as follows:

$$
\operatorname{Prob}\left(M_{i t}=1\right)=\frac{\exp \left(\alpha_{0}+\alpha_{1} R_{i t}+\sum_{j=2}^{k} \alpha_{j} x_{i t}+u_{i}\right)}{1+\exp \left(\alpha_{0}+\alpha_{1} R_{i t}+\sum_{j=2}^{k} \alpha_{j} x_{i t}+u_{i}\right)} .
$$

In order to control for other factors that could have an impact on an employee's decision to change jobs, information about the respondents' satisfaction with their working conditions was used. When estimating equation (4) the author considered two model specifications. The first model used only one additional variable that measures the overall level of individuals' satisfaction with their employment. The second specification incorporated the extended set of additional controls that relate to employees' satisfaction with various aspects of their employment (job security, total pay, the work itself and hours worked). The covariates that denote respondents' satisfaction with working conditions were included as lagged (previous period) variables.

To control for time effects, the study included binary variables that represent each year of the survey. Table 3 contains the operationalizing definitions of the research variables used in the estimation of the logit regression.

Table 3

Operationalizing definitions of the research variables used in the logit regression

\begin{tabular}{l|l|l}
\hline \multicolumn{1}{c|}{ Variables } & \multicolumn{1}{|c}{ Definition } & Type of variable/scale \\
\hline $\begin{array}{l}\text { MOBILE } \\
\text { (outcome variable) }\end{array}$ & $\begin{array}{l}\text { Labour market mobility. Takes value 1 if the } \\
\text { respondent changed the job during the last 12 } \\
\text { months preceding the survey. }\end{array}$ & Dichotomous \\
\hline OCRISK2 & Risk of investment in job-related training. & Numerical \\
\hline L1.JBSAT & $\begin{array}{l}\text { Overall job satisfaction. Lagged variable } \\
\text { derived from the variable JBSAT. }\end{array}$ & Ordinal categorical \\
\hline L1.JBSAT2 & $\begin{array}{l}\text { Job satisfaction: total pay. Lagged variable } \\
\text { derived from the variable JBSAT2. }\end{array}$ & Ordinal categorical \\
\hline L1.JBSAT3 & $\begin{array}{l}\text { Job satisfaction: job security. Lagged variable } \\
\text { derived from the variable JBSAT3. }\end{array}$ & Ordinal categorical \\
\hline L1.JBSAT6 & $\begin{array}{l}\text { Job satisfaction: work itself. Lagged variable } \\
\text { derived from the variable JBSAT6. }\end{array}$ & Ordinal categorical \\
\hline L1.JBSAT7 & $\begin{array}{l}\text { Job satisfaction: hours worked. Lagged variable } \\
\text { derived from the variable JBSAT7. }\end{array}$ & Ordinal categorical \\
\hline WAVE2 - WAVE18 & $\begin{array}{l}\text { Year of the survey. Derived from the variable } \\
\text { WAVE. }\end{array}$ & Dichotomous \\
\hline
\end{tabular}

Source: own elaborations based on BHPS data. 
All steps of the empirical analysis presented in the second and the third sections were carried out using the STATA/SE 13.1 package. The next part of the paper presents and discusses the main results.

\section{RESULTS AND DISCUSSION}

This section do not present the outputs for earnings regression estimation, which are available upon request. Most of the parameter estimates were consistent in sign with the usual assumptions of human capital theory. The estimation results indicated the statistically significant effect of formal education and work experience on employee's hourly wage. The highest rate of return on investment in human capital was confirmed for university graduates. Furthermore, individuals with a job in managerial positions have a higher wage premium ceteris paribus. Additionally, employees of large firms and those with permanent contracts earn higher salaries. Surprisingly, the author observed no statistically significant impact in the case of tenure in a company, with the exception of a few waves. The estimation results confirmed the lower wage premium for female workers and the higher rate of return on investment for married staff.

The study found a positive effect of job-related training on hourly wages, but the parameter estimate was statistically insignificant. However, the inclusion of this variable in the Mincer model was important for two main reasons. Firstly, several studies [De Grip, Heijke and Willems, 1998; Sieben, 2007] provided evidence that participation in job-related training may have an impact on employees' job mobility. Secondly, a lack of return to investment in job-related training is one of the main risk indicators.

Table 4 presents the results obtained from the logit regression for the binary dependent variable which reflects the probability of being mobile in the labour market. The model was estimated using a fixed effects estimator.

The logistic regression coefficients are not directly interpretable because they show the change in the log-odds of the outcome for a one unit increase in the predictor variable. Thus, one can only interpret the signs for the resulting coefficients. A positive sign means that a higher value of the independent variable increases the probability that the dependent variable equals one (job change), whereas a negative sign indicates that a higher value of the predictor variable leads to the higher probability that the dependent variable equals zero (lack of labour market mobility).

From the results presented in the second column in Table 4, it is clear that the probability of changing jobs increases with the risk of investment in training, all else being equal (the estimated regression coefficient for the risk 
has a positive sign). The resulting coefficients for the model with an extended set of independent variables (see the third column in Table 4) also confirm the positive impact of earnings risk on labour market mobility. An increase in employee satisfaction with remuneration, level of security in the workplace and the work itself leads to a lower probability of this individual's mobility in the labour market, while satisfaction with hours worked has no significant impact on whether or not he/she changes jobs.

Table 4

Results of logit model estimation

\begin{tabular}{|c|c|c|}
\hline Independent variables & Model 1 & Model 2 \\
\hline Earnings risk & $\begin{array}{c}0.3359 * * \\
(0.1320)\end{array}$ & $\begin{array}{c}0.3557 * * \\
(0.1323)\end{array}$ \\
\hline Job satisfaction: overall & $\begin{array}{c}-0.2796 * * * \\
(0.0155)\end{array}$ & \\
\hline Job satisfaction: total pay & & $\begin{array}{c}-0.0958 * * * \\
(0.0146)\end{array}$ \\
\hline Job satisfaction: security & & $\begin{array}{c}-0.2020 * * * \\
(0.0143)\end{array}$ \\
\hline Job satisfaction: work itself & & $\begin{array}{c}-0.0969 * * * \\
(0.0168)\end{array}$ \\
\hline Job satisfaction: hours worked & & $\begin{array}{c}0.0039 \\
(0.0163) \\
\end{array}$ \\
\hline Number of observations & 20510 & 20465 \\
\hline Number of individuals & 2659 & 2656 \\
\hline Log likelihood & -7695 & -7635 \\
\hline Chi2 & 1480 & 1562 \\
\hline
\end{tabular}

Source: own computations based on BHPS data.

In the next step of the empirical analysis, the odds ratio was computed. The odds are defined as the ratio of the probability of success (labour market mobility) and the probability of failure (lack of mobility). The odds can range between 0 and infinity. The odds ratio takes values higher than 1 for determinants that increase the probability of labour market mobility and values lower than 1 for determinants that decrease this probability.

The author interpreted the values of the odds ratio calculated on the basis of the results presented in Table 4 as follows: with a one-unit increase of the 
risk of investment in training, an individual's probability of changing job increases by $39.9 \%$. In the case of the model with the extended set of independent variables, the impact is even stronger: a one-unit increase in risk is associated with a $42.7 \%$ increase in the probability of labour market mobility.

The proposed empirical strategy has several limitations. The first is related to the fact that the labour market mobility variable covers only the most recent job change. The total number of job changes in the 12 months preceding the interview was not considered. It would be desirable to examine whether a higher risk of investment in work-related training leads to a higher frequency of job changes.

A major limitation is due to the approach used to estimate the risk of investment in work-related training. Many authors recognize that measuring the risk of investment in human capital is a challenging task, therefore this problem is one of the most discussed in the literature. Buhai [2003] emphasizes that the main drawback of the common approach is that it is based on "insufficient knowledge about the dispersion in returns to education". The main disadvantage of using earnings residuals to measure earnings risk is that they capture the risk related to both recent and previous investments (for example, investment in formal education). Furthermore, earnings variation includes some components that presumably can be predicted by the individual, such as heterogeneous skills [Heckman, Lochner and Todd, 2003]. Earnings residuals can therefore be overestimated and do not fully reflect the risk of investment in job-related training. Further research based on improved estimation procedures is necessary in order to obtain more accurate results.

The estimated risk may be biased as some occupation groups include different and sometimes incomparable professions. As stressed by Hartog and Diaz Serrano [2014], "variance within narrowly defined categories may perhaps very well be equated to risk, while the variance in broader categories may only be risk if the individual does not know what his/her later specialisation will be". Indeed, in the case of some professions (such as lawyers and doctors) an individual's specialisation is more difficult to change in the future, while in other cases individuals are less likely to predict their future job specialisation (this is the case for example, for most economics studies). In this paper, the assumption is that before deciding to engage in job-related training, employees compare the possible outcomes (earnings) not only within their actual occupation, but also between similar jobs in other occupation groups. The sample therefore has to be divided into narrower occupational groups that are 
more homogeneous in terms of job characteristics and occupational skills requirements. Furthermore, as stressed by Kaźmierczyk, Romashkiva and Wyrwa (2020) the perceived usefulness of training can be different for less educated workers and their higher educated counterparts. Therefore the impact of the risk on employees' mobility can vary in different education groups.

The study also suffers from some conceptual limitations. Probably one of the most important is that the analysis did not enable to consider other risks related to investment in work-related training (for example, unemployment risk). Future work could extend the research to the impact of other risks on voluntary job changes.

Finally, the distinction between general and specific job-related training was not taken into account in the study. For employees, investment in specific training is riskier since the possibility of skills utilization is more vulnerable to the constantly changing demand for skills in the labour market [Shelest, 2015]. Thus, it can be hypothesised that the specificity of training completed by an employee could modify the impact of the risk on labour market mobility. This could be another promising subject of future research.

\section{CONCLUDING REMARKS}

The study aimed to investigate the effect of the risk associated with investment in work-related training on labour market mobility in the United Kingdom. It was found that the higher earnings risk of investment in jobrelated training leads to a higher probability of voluntarily changing jobs. This remained true when the author estimated both the restricted model and the model with the extended set of explanatory variables. In the second case, the parameter of interest is even higher, but it still remains statistically significant. The obtained results are an important complement to the limited existing empirical research on the risk of investment in human capital and its impact on individual career choices. The finding is not straightforward because the risk of investment in job-related training is also taken by the employer and hence may increase involuntary job mobility.

These research findings cannot be directly compared with the previous results as the effect of the risk of investment in human capital on employees' mobility remains scantily addressed in the literature. Nonetheless, the findings suggest that the risk of investment in work-related training cannot be neglected in job-specific skills development programmes and career planning, as it may have a significant impact on employees' labour market mobility. 


\section{REFERENCES}

Andreß, H.-J., Golsc,h K., Schmidt, A. W., Applied panel data analysis for economic and social surveys. Springer Science \& Business Media, 2013.

Argaw, B. A., Maier, M. F., Skriabikova, O. J., Risk attitudes, job mobility and subsequent wage growth, ZEW - Centre for European Economic Research Discussion Paper, 17-023, https:// papers.ssrn.com/sol3/papers.cfm?abstract_id=2977217, accessed on 9.08.2018, 2013.

Bonin, H., Dohmen, T., Falk, A., Huffman, D., Sunde, U., Cross-sectional earnings risk and occupational sorting: The role of risk attitudes, Labour Economics, Vol. 14, No. 6, pp. 926 937, 2007.

Booth, A. L., Francesconi, M., Zoega, G., Unions, Work-Related Training, and Wages: Evidence for British Men, Industrial and Labor Relations Review, Vol. 57, No. 1, pp. 68-91, 2003.

Buhai, S., On Risk in Educational Choice: Brief Overview and Research Note, Working Paper, Tinbergen Institute Amsterdam and Erasmus University Rotterdam, http://www. sebastianbuhai.com/papers/others/risky_education.pdf, accessed on 12.08.2018, 2003.

Cheng, X., Risk in human capital investment and gender difference in adult college enrollment, $\mathrm{PhD}$ dissertation, Ohio State University, 2007.

De Grip, A., Heijke, H., Willems, E., Training and mobility, The Netherlands' Journal of Social Sciences, No. 34, pp. 78-98, 1998.

Diaz-Serrano, L., Hartog, J., Skyt Nielsen, H., Compensating Wage Differentials for Schooling Risk in Denmark, Scandinavian Journal of Economics, Vol. 110, No. 4, pp. 711-731, 2008.

Diaz Serrano, L., Hartog, J., Earnings risk and demand for higher education: a cross-section test for Spain, Journal of Applied Economics, Vol. X, No. 1, pp. 1-28, 2007.

European Commission (2016), A new skills agenda for Europe, Brussels, https://ec.europa.eu/ transparency/regdoc/rep/1/2016/EN/1-2016-381-EN-F1-1.PDF, accessed on 4.09.2019

Ferreira, M., Künn-Nelen, A., De Grip, A., Work-related learning and skill development in Europe: Does initial skill mismatch matter?, Research in Labor Economics, Vol. 45, (Skill Mismatch in Labor Markets), pp. 345-407, 2017.

Flisi, S., Goglio, V., Meroni, E. C., Rodrigues, M., Vera-Toscano, E., Measuring occupational mismatch: Overeducation and overskill in Europe - evidence from PIAAC, Social Indicators Research, Vol. 131, No. 3, pp. 1211-1249, 2017.

Hartog J., Diaz-Serrano L., Is there a risk-return trade-off across occupations? Evidence from Spain, IZA Discussion Paper, 1355, 2004.

Hartog, J., Diaz Serrano, L., Why do we ignore risk in schooling decisions?, Paper presented at the XXIII Meeting of the Economics of Education Association, Valencia 2014.

Hartog, J., Ding, X., Liao, J., Is earnings uncertainty relevant for educational choice? An empirical analysis for China, IZA Discussion Paper, 5679, 2011.

Hartog, J., Vijverberg, W. P. M., Do wages really compensate for risk aversion and skewness affection?, IZA Discussion Paper, 426, 2002.

Heckman, J. J., Lochner, L. J., Todd, P. E., Fifty years of Mincer earnings regressions, NBER Working Paper, 9732. National Bureau of Economic Research, https://www.nber.org/ papers/w9732.pdf, accessed on 12.08.2018, 2003. 
Kaźmierczyk, J., Romashkina, G. F., Wyrwa, J., The value of training and loyalty. A comparative analysis, Entrepreneurship and Sustainability Issues, Vol. 8, No. 1, pp. 762-779, 2020.

King, A.G., Occupational choice, risk aversion, and wealth, Industrial and Labor Relations Review, Vol. 27, No. 4, pp. 586-596, 1974.

Kodde, D. A., Uncertainty and the demand for education, The Review of Economics and Statistics, Vol. 68, No. 3, pp. 460-467, 1986.

Mavromaras, K., McGuinness, S., Richardson, S., Sloane, P., Wei, Z., Over-skilling and job satisfaction in the Australian labour force, NCVER Adelaide, https://www.ncver.edu.au/ data/assets/file/0017/3068/2365.pdf, accessed on 2.09.2019, 2011.

McGoldrick, K., Do women receive compensating wages for earnings uncertainty?, Southern Economic Journal, Vol. 62, No. 1, pp. 210-222, 1995.

McGoldrick, K., Robst, J., The effect of worker mobility on compensating wages for earnings risk, Applied Economics, Vol. 28, No. 2, pp. 221-232, 1996.

Meliciani, V., Radicchia, D., Overeducation and overskill in the Italian labour market: the role of fields of study, CIMR Research Working Paper Series, Working Paper No. 33. Roma, http://www.bbk.ac.uk/innovation/publications/docs/WP33.pdf, accessed on 2.09.2019, 2016.

Morgan, S. L. (ed.), Handbook of causal analysis for social research, Springer 2013.

OECD, OECD Employment Outlook, OECD Publishing, http:/www.oecd-ilibrary.org/ employment/oecd-employment-outlook-2014_empl_outlook-2014-en, accessed on 7.11.2018, 2014.

Raita, S., The risk of investment in human capital, $\mathrm{PhD}$ dissertation, Research Institute in Economics and Econometrics Amsterdam (RESAM), Amsterdam 2005.

Shelest, O., Risk of investments in human capital and expected worker mobility, International Journal of Management and Economics, Vol. 47, No. 1, pp. 82-106, 2015.

Sieben, I., Does training trigger turnover - or not? The impact of formal training on graduates' job search behaviour, Work, Employment \& Society, No. 21, pp. 397-416, 2007.

Received: October 2019, revised: May 2020

Acknowledgement: Financial support for this paper was provided by the National Science Centre (grant UMO-2013/11/N/HS4/02969). 